\title{
AVERROES, VIDA Y PERSECUCIÓN DE UN FILÓSOFO
}

\author{
Josep Puig Montada \\ Universidad Complutense de Madrid
}

\begin{abstract}
RESUMEN
La literatura medieval árabe abunda en el género biográfico, aunque éste suele seguir un modelo fijo. Cada personaje, reconocido por su producción literaria o actividad profesional, es regisrado. Se nos informa de su familia, de sus maestros y de sus discípulos, de sus cargos, de sus obras, y de la fecha de su muerte. En el pesente artículo he utilizado los materiales más bien esquemáticos que proporcionan obras de este género y he dibujado el contexto social de Averroes consiguiendo una imagen que ayuda a comprender la falta de continuidad de la ecuela de Averroes en el mundo árabe, después de su muerte en 1118.
\end{abstract}

Palabras clave: Averroes, Biografía, Almohades, Historia cultural.

\begin{abstract}
Arabic medieval literature has recourse to many biographical directionaries, but the information they supply mostly conforms to a standardized pattern. They registre every individual whose literary production or professional activity was valued and list ancestors, teachers and disciples, the offices served, the works writen, and the date and place of death. In this article, using this rather programmatic informtion, I have been able to generate a picture of the social context of Averroes, which helps explain the dissipation of his influence of Averoes in the Arab word immediately following his death in 1198.
\end{abstract}

Key words: Averroes, Biography, Almohads, Cultural history.

En la noche del jueves al viernes, 10-11 de diciembre 1198, 9 Șafar 595, falleció en Marrakesh, capital del imperio almohade, Abû l-Walîd Muhammad Ibn Rushd, Averroes para los latinos. Averroes no sólo fue el gran comentador de Aristóteles sino también artífice de un sistema filosófico original, que hemos aprendido a valorar deshaciéndonos de viejos prejuicios en contra de la edad media o del mundo islámico. Pero el objeto de este artículo no es dar a conocer este pensamiento, ni siquiera sus rasgos más significativos, sino que dando por supuesta su importancia, queremos seguir la experiencia vital de Averroes, desde su educación hasta su persecución, viendo siempre a este hombre en su contexto: 


\section{CONTEXTO POLÍTICO}

La vida de Averroes comprende un espacio de tiempo que va desde los últimos años de los almorávides hasta el apogeo de los almohades, dos dinastías beréberes cuyo dominio se extendió a ambos lados del Estrecho.

'Alî bn Yûsuf Ibn Tâshufîn era el sultán almorávide (500/1 106-537/1143), cuando Averroes nació en 520/1126. Hacia 1118, Muhammad Ibn Tûmart, beréber de la tribu de los Maḥmûda, regesaba a su tierra natal, después de su largo viaje, primero a Córdoba (sobre 1106) y luego a oriente «en busca de la ciencia»; comenzaba así un movimiento doctrinal y político, el almohade, que reemplazaría a los almorávides.

De las diversas doctrinas defendidas por Ibn Tûmart destaca la del mahdî: Dios enviará un profeta o mahdî, antes del fin del mundo para llevar la justicia a la humanidad y prepararla para el día del juicio. En 1121, los seguidores de Ibn Tûmart lo proclaman $m a h d \hat{l}^{1}$ y la aldea de Tinmel, en el Alto Atlas, se convierte en el centro del movimiento que al principio no se extiende más allá de su tribu.

Cuando Ibn Tûmart muere en 1130, le sucede al frente de los almohades 'Abd al-Mu'min ibn 'Alî (524/1130-558/1163), quien consigue derrotar a los almorávides, tras un debilitamiento progresivo de estos. En la primavera de 1147, toma Marrakesh, la capital del imperio, y en este mismo año Sevilla se entrega a sus fuerzas.

La debilidad almorávide dio lugar a una serie de revueltas en diversas ciudades andalusíes, que vivieron lo que se denomina «segunda época de taifas». En 539/1 145, un emirato independiente se instaura en Córdoba, pero de poca duración. Parece que sus habitantes prefirieron la protección almorávide, dirigida por Yahyà Ibn Ghâniya, que se mantuvo hasta 1149, cuando los almohades finalmente se hacen con la ciudad. En otros lugares, los almohades necesitan más tiempo para su control de modo que hasta 568/1172 no dominan totalmente la parte peninsular de Al-Andalus. En 1145 Averroes tenía ya 19 años y debía de seguir estos acontencimientos de cerca y con conocimiento directo; aun más, en 1153, Averroes se encuentra de visita en Marrakesh, la capital del nuevo imperio.

'Abd al-Mu'min nombró a su hijo Abû Ya'qûb Yûsuf gobernador de Sevilla, sobre 1156-7. Durante su estancia en Sevilla, Abû Ya 'qûb se rodeó de intelectuales, entre ellos Abû Bakr Ibn Țufail (m. 581/1185), que le acompañó a Marrakesh cuando se convirtió en el nuevo califa. Esto sucedió en 558/1163 a la muerte de 'Abd al-Mu'min, su padre. Averroes formaba parte del círculo estrecho de consejeros del sultán, a quien acompañó durante su fracasada expedición contra Huete, en 1172. En 578/1182 el sultán llamó a Averroes a Marrakesh para que fuera su médico. Dos años más tarde, Abû Ya quûb tuvo que regresar a la península para hacer frente al avance de los ejércitos cristianos, en este casos portugueses, que se habían apoderado de Santarem, e intentó recobrar esta fortaleza, pero murió en el asedio (580/1184).

1 'Abd al-Mu'min, el primero de los diez seguidores, le dice «Tu eres el mahdî̀. Al-hulal al-mawshîya, ed. I.S. Allouche (Rabat, 1936), pp. 87-88; tr. española A. Huici Miranda (Tetuán, 1952), p. 128. 
Abû Ya 'qûb aparece como un hombre culto, conocedor tanto de las ciencias coránicas como de los antiguos. Simpatizaba con el zâhirismo pero públicamente no se pronunció. En cambio, su hijo y sucesor Abû Yûsuf Ya'qûb al-Manșûr (1184-1199), que era más un hombre de religión, adoptó la doctrina zâhirî, y se apartó de la escuela mâlikí, predominante en al-Andalus². Abû Yûsuf tenía un hermano, Abû Yahyà Zakariyâ, que era gobernador de Córdoba y sabemos que Averroes tenía amistad, ikhtișâss, con él. Como el sultán sospechaba que su hermano Zakariyâ conspiraba contra él, lo hizo venir a Marrakesh y lo mandó matar.

Abû Yûsuf al-Manșûr fue un hombre de guerra. En 1194 se trasladó a la península para combatir las tropas castellanas, que el año antes habían castigado al-Andalus y derrotó al rey de Castilla, Alfonso VIII (1169-1214) en la batalla de Alarcos, 591/1195. Luego se aseguró el triunfo pactando con el rey de León Alfonso IX (1188-1229), y con el de Navarra Sancho VII (1194-1234).

Averroes murió el 9 Șafar 595, es decir, 10-11 diciembre 1198, y un mes más tarde, ya en 1199, el califa al-Manșûr. Le sucedió Muhammad an-Nâșiir, el Miramamolín de las crónicas cristianas, pero éste tuvo que hacer frente a una coalición de los reyes cristianos, que le derrotaron en la batalla de Las Navas de Tolosa, el 16 de julio 1212, batalla que las crónicas árabes denominan al-'Iqâb, la «de los puertos de montaña», y mal merece el sobrenombre de an-Nâșir «el vencedor».

\section{LA FAMILIA IBN RUSHD}

El primer miembro de la familia Ibn Rushd del que tenemos noticias es el bisabuelo de Averroes llamado Aḥmad bn Aḥmad bn Aḥmad bn 'Abd Allâh Ibn Rushd y según al-Awsî alMarrâkushî todavía vivía en 482/1089. En esta fecha, Córdoba dependía de la taifa de Sevilla.

El abuelo de Averroes ya es un personaje muy conocido, hasta el punto que a Averroes para distinguirlo del abuelo lo llamaban al-hafid, «el nieto», o al-asghar, «el pequeño», mientras el abuelo tenía el sobrenombre de al-akbar, «el mayor», al-qâd $d \hat{\imath}$, «el juez» y por supuesto, al-jadd, «el abuelo». Averroes y su abuelo llevaban el mismo nombre y kunyà: Abû l-Walîd Muhammad. Había nacido en Córdoba en Shawwâl 450/1058, cuando Muhammad Ibn Jawhar era señor de la taifa cordobesa (1043-1064).

Abû l-Walîd al-jadd llegó a ser una autoridad en el derecho mâlikî, y numerosas fetwas lo atestiguan. Entre sus obras señalo el Kitâb al-muqaddimât wal-mumahhadât a la Mudawwana del imam Mâlik, y los 20 volúmenes del Kitâb al-bayân wa-t-tahşill, pero también sus resúmenes del Mushkil al-âthâr, que es obra-de un autor hanafî, aț-Tahâwî, como muestra de la amplitud de sus conocimientos.

Su conocimiento del ash'arismo es otra prueba de su competencia. La doctrina de Abû l-Ḥasan al-Ash'arî (873-935) no recibe su reconocimiento oficial hasta tiempos de los seljucos, y gracias a la protección del gran ministro Nizâm al-Mulk (465/1072-485/1092). Al-Ash'arî reforma la teología mu tazilí y la hace aceptable desde el punto de vista de la religosidad tradicional, de modo que

2 Abû l-Husain Ibn al-Athîr, Al-kâmil fî t-târîkh. Ed. C.J. Tornberg (1853. Reprint Beirut, 1966), vol. XII, pp. 145146. 
en la fecha que nos ocupa, debe de presentarse como la única aceptable. Así preguntaron al abuelo de Averroes por la ortodoxia de los ash'aríes, cosa que siempre defendió. Ahora bien, en cuanto a si la verdadera fe y religión, al-îmân wa-l-islâm, solamente son posibles mediante «el análisis y el razonamiento efectuados siguiendo las normas establecidas por los ash'aríes», Averroes al-jadd dictaminó que de ningún modo era necesario seguir a los ash 'aríes, aunque sus ciencias fueran verdaderas. Por el contrario no conviene que las gentes sencillas se confundan oyendo éstas, sino que deben seguir las instrucciones claras del Corán. ${ }^{3}$

Una opinión como ésta no podía más que complacer a los almorávides, recelosos del Kalâm y del Algacel, y del que finalmente se distancian. Ellos habían nombrado a Ibn Rushd abuelo juez de Córdoba (1117), cargo al que él mismo renunciaría para consagrarse a sus estudios. Según el cronista del Raw dal-qirtâss, sin embargo, fue el mismo emir 'Alî bn Yûsuf Ibn Tâshufîn (1106-1143) quien lo destituyó en 513/1119 y en su lugar nombró a su rival Abû l-Qâsim Ahmad Ibn Hịamdîn at-Taghlabî (m. 521/1127), conocido también por haber instigado la quema de la Vivificación de las ciencias de la religión, la obra más importante de Algacel, hacia 1109.

En cualquier caso, el abuelo de Averroes mantuvo su posición de prestigio, pues unos años más tarde vemos cómo encabeza una delegación cordobesa que se desplazó a Marrakesh y fue recibida por el emir citado. El motivo del viaje está relacionado con la expedición del rey de Aragón Alfonso el Batallador por tierras andalusíes en el año 519/1125. Alfonso derrotó a Tamîm Ibn Yûsuf en la batalla de Aranzul (cerca de Lucena) el 9 de marzo 1126 y después saqueó al-Andalus con ayuda de muchos mozárabes que luego le siguieron cuando regresó a Aragón.

Pero no todos los cristianos abandonaron al-Andalus, y los que se quedaron representaban un peligro para el país debilitado. En su informe, el abuelo de Averroes consideraba que estos cristianos eran reos de traición, pero que no debía ser ejecutados, sino deportados y consiguió del emir que en efecto, ordenara su deportación al otro lado del Estrecho en Ramaḍân 520 (Septiembre-octubre 1126). Ibn Rushd al-Mâlikî enfermó en el viaje de regreso y murió en Córdoba el 21 Dhû lQa'da 520, 8 diciembre 1126.

El padre de Averroes, que se llamaba Ahmad y llevaba por kunyyà Abû l-Qâsim, había nacido en 487/1094. Fue también jurista, aunque carecía del prestigio que tuvo su padre, y también llegó a ser juez de Córdoba pero por poco tiempo. 'Alî bn Yûsuf, el mismo que había nombrado juez a su padre, dio el cargo en 529 a Abû Ja 'far H̦amdîn Ibn Ḥamdîn at-Taghlabî, hijo del anterior Ibn Ḥamdîn, pero lo destituyó en 532/1138. No cabe duda de que la familia Ibn Ḥamdîn no apoyaba a los almorávides, o por lo menos no tanto como la familia Ibn Rushd. Así el sultán puso en su lugar al padre de Averroes, pero este no fue aceptado por sus conciudadanos. El mismo año hubo una revuelta, y Abû l-Qâsim renunció a su cargo. El sultán optó por dejar Córdoba sin qâậ al-qudậ durante un año, luego permitió elegir uno, y las preferencias de los cordobeses se inclinaron de nuevo por Abû Ja far Ḥamdîn Ibn Ḥamdîn. En 1145 se convirtió en emir al-Manșîr bi-l-Lâh, pero solamente disfrutó de su poder en dos períodos de 14 meses: 1144-1145 y 1145-1146.

3 Reproducida por Jamâl ad-Dîn al-'Alawî, Al-matn ar-rushdî (Casablanca, 1986), pp. 198-199. Otras fetwas se encuentran en V. Lagardère, «Une théologie dogmatique de la frontière en al-Andalus aux XIe et XIIe siècles: l'aš"arisme», Anaquel de estudios árabes, 5 (1994), pp. 93-97. 
Averroes nació en 520/1126, un mes antes de la muerte de su abuelo. Su padre fue uno de sus maestros, tal como él lo sería de sus hijos. Del mayor, Walîd, no tenemos información, pero sí de otros dos: Ahmmad y 'Abd Allâh. Abû l-Qâsim Aḥmad (m. 622/1225) siguió la tradición jurista y fue juez en varias ciudades andalusíes. Abû Muhammad 'Abd Allâh destacó en la medicina, e Ibn Abî Uṣaibi'a nos dice que fue médico del sultán an-Nâșir Miramamolín (1199-1213)4. Además de escribir de medicina, junto con su padre compuso un tratado acerca de «La conjunción del entendimiento separado con el hombre.» 'Abd Allâh acompañaba a su padre el día en que entraron en la mezquita de Córdoba para la oración de media tarde, y una gentuza los expulsó, algo que Averroes recuerda como la mayor desgracia que jamás le afectó.

Abû 1-'Abbâs Yahyà puede hijo de Abû Muhammad. Nieto, en cualquier caso, de Averroes, es autor de los indices de obras de Alfarabi, Averroes y Avicena que aparecen en los folios $81 \mathrm{r}^{\circ}-83$ $v^{0}$ del manuscrito escurialense Árabe 884.

A la familia Ibn Rushd pertenece también un personaje llamado Abû I-Qâsim Ahmad alWarrâq «el librero», que nació en Córdoba en 513/1119 y murió en Marrakesh en 582/1186. Utilizaba la nisba de al-Qaisî y enseñó el derecho o fiqh a personas que también era discípulos de Averroes.

\section{LA EDUCACIÓN DE AVERROES}

Averroes recibió la educación habitual en el medio al que su familia pertenecía. Abû Muhammad Ibn Rizq le enseñó el Corán, es decir, las primeras letras en el sistema musulmán. No he podido encontrar más información sobre él, pero Ibn Rizq es un nombre relacionado con la familia Ibn Rushd. El abuelo de Averroes fue discípulo de Abû Ja'far Ahmad Ibn Rizq (427/1037477/1084), reconocido juristà y jefe de los consejeros legales, shûrà, en Córdoba. Abû Ja 'far tuvo un hijo, también jurista y además hâfiz del texto sagrado, llamado Abû Bakr 'Umar bn Ahmad Ibn Rizq (m. 507/1113-4). Abû Muhammad, el maestro de Averroes, puede ser nieto del maestro del abuelo de Averroes.

Después del Corán, un niño aprendía là poesía clásica. Averroes se sabía el dîwân de alMutanabbi' y el de Abû Tammâm; en sus obras demuestra un buen conocimiento de la poesía clásica, con citas variadas. Esta formación filológica se la dio Abû Bakr Ibn Samajûn (o Samahûun, m. 563/1168), quien además de la poesía le enseñó el Corán, y matemáticas.

El derecho, lógicamente, debía constituir el estudio principal de Averroes. Su primer maestro fue su propio padre. Está luego Abû l-Qâsim Khalaf Ibn Bashkuwâl (Córdoba, 495/1101-578/11823), un hombre que conocía los hadices, el fiqh y que compuso un conocido repertorio bio-bibliográfico, Kitâb as-șilat fî ta'rîkh a'immat al-Andalus. Durante un tiempo Ibn Baschkuwâl fue juez, ayudando a Abû Bakr Ibn al-'Arabî (468/1075-545/1149). Este segundo conocía bien el Kalâm ash'arí y dio a conocer a Algacel en al-Andalus. 
Abû Bakr Ibn al-'Arabî acompañó con 21 años a su padre Abû Muhammad, en su peregrinación a Meca en 489/1096. Su padre pidió a Algacel que emitiera una conocida fetwa legitimando a los almorávides, que por aquellas fechas ya dominaban ambas orillas del Estrecho y cuando todavía no existía el peligro almohade. ${ }^{5}$ Abû Bakr estudió con Algacel, mereció sus elogios, y a su regreso a al-Andalus, fue juez de Sevilla y maestro reconocido, hasta que el creciente peligro almohade fue su desgracia.

Averroes estudió también con Abû Marwân Ibn Masarra (m. 552/1157), discípulo y amigo de su abuelo, y considera a Ibn Masarra nada menos que su shaikh o «maestro». Fue también discípulo de Abû Ja'far Ibn 'Abd al-'Azîz (m. Córdoba, 533/1139), una figura menor.

Abû l-Faḍl 'Iyâd, el famoso qậ̣̂̂ 'Iyâd, tuvo a Averroes entre sus estudiantes cordobeses. Había nacido en Ceuta en 476/1083 y estudiado en al-Andalus, con el abuelo de Averroes, entre otros maestros, y con Abû 'Abd Allâh Muḥammad Ibn Ḥamdîn (439/1047-508/1115), jurista mâlikí. Sabemos que en 531/1136 fue nombrado juez en Granada, y que a partir de 534 enseñó en Córdoba, y que en 539 Ibrâhîm Ibn Tâshufîn lo hizo juez de Ceuta.

'Iyâd encarnaba la ortodoxia mâlikí y la reacción frente a la renovación de Algacel, siendo por ello una figura representativa del pensamiento almorávide. ${ }^{6}$ Los almohades ocuparon Ceuta, cuando 'Iyậ había vuelto a ella, pero la ciudad se rebeló contra los nuevos señores. Ignoramos el papel de 'Iyâd en la revuelta, pero fue deportado a Marrakesh, donde murió en 544/1149.

Todos estos maestros de Averroes pertenecían al rito mâlikí, y un jurista mâlikí le dio una ijâza, o licencia para enseñar su obra, algo que se puede hacer por escrito, sin necesidad de estar presente el que la recibe. Quien le dio esta ijâza fue el imâm al-Mâzarî, representante destacado del rito mâlikí. Abû 'Abd Allâh Muhammad al-Mâzarî nació en Mahdiya (Túnez) en 453/1061 y murió allí en 536/1141. Al-Mâzarî se opuso a Algacel y llegó a escribir una refutación de la gran obra de este, la Ihyấ ' ulûm ad-dîn por la filosofía y el sufismo contenidos en la obra. ${ }^{7}$ Teniendo en cuenta que murió en 1141, cuando Averroes tenía 15, como mucho 16 años, podemos imaginar que el padre de Averroes medió en la obtención de esta prestigiosa ijâza.

Algo nuevo en la tradición familiar fueron los estudios de medicina que hizo Averroes. Conocemos a dos de sus maestros en el arte médica: Abû Màwân 'Ạbd al-Mâlik Ibn Juryûl y Abû Ja'far Ibn Hârûn aṭ-Turjâlî. Ibn Juryûl (=Gudriol) era valenciano, aunque vivía en Córdoba. Es conocido también como Ibn Qabburât e Ibn Kanburât.

El segundo llevaba la nisba de la ciudad de Trujillo, por su origen, pero la fuente, es decir Ibn Abî Ușaibî'a, precisa que vivía en Sevilla, y había sido alumno de Abû Bakr Ibn al-'Arabî, que le entrenó en los hadices. Destacó en la medicina y la farmacia, siendo médico del sultán Abû Ya 'qûb Yûsuf, el protector de Averroes. A Averroes le enseñó medicina y matemáticas, pero sin duda también filosofía, puesto que estudiaba los libros de Aristóteles y demás sabios griegos. Los conocimientos matemáticos de Averroes no son despréciables, pues le permitieron redactar un compendio del Almagesto de Ptolomeo.

5 Véase el estudio reciente de Madeleine G. Fletcher, «Ibn Tûmart's Teachers: The Relationship with al-Ghazâlî, Al-qantara, 18 (1997) 305-328.

6 Hanna E. Kassis, «Iyâđ̛̣ s Doctrinal Views and their Impact on the Maghreb», The Maghreb Review, 12 (1988) 49-56.

7 Para una información actualizada de su figura, que fue estudiada por M. Asín Palacios ya en 1910, («Un faqih siciliano contradictor de al-Gazzâlî, Abû 'Abd Allâh de Mazara»), pueden verse pp. 691-697 de Abdel-Magid Turki, «Consultation juridique d'al-Imâm al-Mâzarî sur le cas des musulmans vivant en Sicile sous l'autorité des normands», Mélanges de l'Université Saint Joseph, 50:2 (1984). 


\section{EL CÍRCULO PRÓXIMO DE AVERROES}

Otro médico del círculo de Averroes fue Abû Bakr Muhammad Ibn Túfail, quien había nacido en Guadix entre $510-520 \mathrm{H}$ y era algo más joven que ese. Ibn Tufail tenía gran amplitud de conocimientos, desde los hadices hasta la astronomía y también simpatizaba con el sufismo. Solamente conservamos una obra suya, la Risâlat Hayy Ibn Yaqzân, traducida al español como «El filósofo autodidacta» y donde defiende que la razón, por sí misma, llega a los mismos resultados que la religión revelada. Ibn Tufail es el único seguidor de Avicena en al-Andalus.

Los califas almohades, primero 'Abd al-Mu'min y luego Abû Ya'qûub Yûsuf, a quien sirvió como médico hasta 578/1182, le dispensaron sus favores. Ibn Tufail apreciaba a Averroes, y como disfrutaba de una posicion privilegiada en la corte almohade, él fue quien presentó a Averroes ante Abû Ya'qûb en una fecha que se suele situar en 1168. Averroes había escrito ya varias obras, de medicina, derecho y filosofía, y tenía más tiempo que Ibn Ṭufail, muy ocupado en cuestiones de gobierno. El sultán le había pedido a Ibn Tufail que escribiera unas exposiciones de las obras de Aristóteles, que le resultaban difíciles de leer. La escena, descrita por al-Marrâkushî, es bien conocida.

Al-Marrâkushî se basa en la información que le proporcionó un discípulo y amigo de Averroes, Abû Bakr Bundûd Ibn Bundûd bn Yahyyà al-Qurțubî. En la biblioteca de El Escorial, el manuscrito árabe 627 contiene un breve comentario suyo a la Urjîza (poema en pie rajaz) lógica de Avicena y esto es todo lo que sabemos de él.

Bundûd aparece una segunda vez en relación con Averroes: Cuando era qâậ̀ de Córdoba, el gobernador de la ciudad lo mandó llamar para una consulta. En oriente y al-Andalus circulaba el rumor de que un viento arrasador soplaría en determinada fecha acabando con la vida humana, y las gentes estaban aterrorizadas. Averroes e Ibn Bundûd después de la audiencia, hablaban de las causas naturales de los vientos, pero les acompañaba un tal 'Abd al-Kabîr al-Ghâfiqî (536/1141617/1220), hombre muy piadoso, quien observó: «Si este viento se produce, será una continuación del viento aquel que Dios utilizó para destruir al pueblo de 'Âd, pues después no se ha conocido ningún viento con tales efectos». El racionalista Averroes, para escándalo de al-Ghâfiqî y de los demás presentes, contestó «El pueblo de 'Âd nunca existió, ¿cómo se pudo destruir algo que no existió?».

Uno tiende a creer que al-Ghâfiqî difundió esta historia solamente cuando Averroes había caído en desgracia, porque antes había sido su discípulo y amigo. Estudió la medicina y el derecho, destacando en la ciencia notarial, y llegó a ser juez principal en Ronda. Gozaba de la confianza de Averroes de tal modo que lo representaba en los estrados de la ciudad.

El propio 'Abd al-Kabîì al-Ghâfiqî sufrió una de estas persecuciones o mihnna, después de la muerte de Averroes. Según nos informa Ru'ainî, que se refiere a al-Ghâfiqî como su shaikh, éste fue víctima de la represión que se produjo en 595/1200, en tiempos de Miramamolín, pero tuvo suerte, pudo esconderse y reaparecer cuando la situación se normalizó ( $\mathrm{Ru}$ 'ainî silencia el hecho de que fuera discípulo y amigo de Averroes). Mientras al-Ghâfiqî consiguió así evitar la cárcel, Abû Bakr Muhammad Ibn Khalaf at-Tujîîî y Abû 1-Ḥusain Aḥmad Ibn Zarqûn, ${ }^{8}$ con los que había hecho la peregrinación a Meca, pasaron un tiempo en ella. Hay que observar que esta mihna no iba dirigida solamente contra los filósofos, pues este Ibn Zarqûn era mâlikí y había escrito refutaciones de 
las dos obras jurídicas, más importanes, de Ibn Hazm, al-Muhallâ y al-Mujallà. Dado que Ibn Ḥazm se convirtió en el verdadero ideólogo del almohadismo, salta a la vista la gravedad del ataque de Ibn Zarqûn. Por lo demás, las fuentes culpan de la persecución al médico y vesir Abû Bakr Ibn Zuhr, hijo de un Avenzoar amigo de Averroes, que murió poco después de su mihnna (m. 596).

A través de una de estas persecuciones «inquisitoriales", podemos conocer los nombres de otros miembros del círculo de Averroes. En 593/1197, Averroes mismo fue perseguido junto con otros filósofos: Abû Ja far Aḥmad Ibn Jurj adh-Dhahabî, Abû 'Abd Allâh Muḥammad Ibn Ibrâhîm al-Mahrî al-Ușûlî, Abû r-Rabî' al-Kafîf y Abû l-'Abbâs al-Qarrâbî.

Abû Ja'far (o Abû l-'Abbâs) Ahmad adh-Dhahabî nació en Valencia en 554/1159 y murió en Tremecén en 601/1204, acompañando al califa an-Nâșir en su expedición contra Túnez. Entre sus maestros figuran Ibn Madâa', Ibn Bîbish e Ibn al-Mughîth; Averroes no aparece mencionado, pero el silencio puede ser consecuencia, una vez más, de la represión. Entre sus discípulos cuento al hijo de at-Tujîibî antes mencionado. Adh-Dhahabî era médico, sirviendo a los dos califas, Abû Yûsuf alManșûr y Muḥammad an-Nâșîr.

Al-Awsî al-Marrâkushî afirma que adh-Dhahabî «era el que más sabía de ciencias de los antiguos y de matemáticas», y que tenía conocimientos extraordinarios en Ias demás ciencias. El califa Abû Yûsuf al-Manșûr lo llamó a su Marrakesh, y disfrutó de un alto rango tanto en su corte como en la de su hijo Abû 'Abd Allâh an-Nâsșir. Adh-Dhahabî era el responsable del asesoramiento legal, shîrà wa-fatwà, y emitía los dictámenes necesitados en los juicios. Abû l-'Abbâs Ibn Jawhar, que supervisaba el rito mâlikî, protestó pero en vano y lạ fama de los conocimientos de Abû Ja 'far adhDhahabî se consolidó. Es fácil imaginar que Ibn Jawhar y otros mâlikíes alentaron la persecución, de la que logró escapar ocultándose en Castro del Río. Más tarde, cuando Averroes y al-Mahrî alUșûlî fueron amnistiados, reapareció y al-Manșûr lo honró aún más.

Estamos pues ante tres autoridades intelectuales, muy vinculadas a los almohades: Averroes, adh-Dhahabî y al-Ușûlî. Éste pertenecía a una familia sevillana muy conocida, los Banû Marzuqân. Viajó a oriente «en busca de la ciencia», y en Alejandría asistió a las sesiones de Abû ț-Ṭâhir Ibn 'Awf as-Salafî, pero este le consideró un hereje y le expulsó de la ciudad. Pasó un tiempo en «las islas de Banî Mazghanâ» (Argel) y terminó en Marrakesh, donde tuvo muchos alumnos; en Bugía completará su tarea docente. Al-Mahrî descolló en el conocimiento del Kalâm y de los fundamentos del derecho, de tal modo que se le conocía por al-Ușûlî, «el fundamentalista», claro está, en el sentido original del término.

Algacel compuso un obra acerca de los fundamentos del derecho llamada Al-mustasfà min 'ilm al-ușull, ${ }^{9}$ que se convierte en una obra básica en este periodo y sobre la que Averroes y al-Ușûlî escribieron comentarios; al-Awsî al-Marrâkushî precisa que al-Ușûlî «corrigió los defectos del Mustasfà̀.

Las ciencias de los antiguos atrajeron también su interés. Cuando los alfaquíes cordobeses consiguen, en 1197, que al-Manșûr los reúna en la mezquita para condenar a Averroes, Abû 'Abd Allâh al-Uș̂ulî también tiene que comparecer. Al-Awsî al-Marrâkushî no nos habla de su suerte, pero lo más probable es que tuviera que alejarse y cruzar el Estrecho.

9. Todavía muy difundida, 2 vols. $1^{a}$ ed. Bûlâq, 1323/1905; $3^{\text {a }}$ ed. (Reprint), Beirut, 1993. Averroes escribió un comentario, Ad-darûrî fî ușul al-fiqh, ed. J. Al-'Alawî, Beirut, 1994. 
En Marrakesh, frecuentaba las sesiones de al-Manșûr, pero no dejó de interesarse por la filosofía. El califa le preguntó si seguía estudiando las mismas ciencias a causa de las cuales Averroes había perdido su favor, y al-Uṣûlî tuvo la valentía de reconocerlo. Desterrado a Aghmat, fue perdonado y honrado con el puesto de juez principal en Bugía. Más tarde fue juez de Murcia, sustituto del juez de Marrakesh, y otra vez juez de Bugía.

Corría el año 608/1211-2, cuando fue destituido de su cargo y torturado por el gobernador de Bugía, Abû 'Abd Allâh Ibn Yûmûr al-Harghî, que incluso azotó a su hijo, «una prueba muy dura» para Abû 'Abd Allâh al-Ușûlî que murió ciego en Bugía el año 612/1216.

Hemos visto pues un grupo de amigos de Averroes, juristas, a la vez que interesados en las ciencias de los antiguos. El caso de Abû Marwân Ibn Zuhr es similar. Abû Marwân, unos treinta años mayor que Averroes, procedía de una familia sevillana también con una tradición intelectual, en este caso una familia de médicos.

Los Banû Zuhr fueron médicos de los emires almorávides, pero Abû Marwân tuvo serias dificultades con 'Alî Ibn Yûsuf. Prestó sus servicios a los nuevos señores como médico del primer califa almohade, 'Abd al-Mu'min. Su hijo, Abû Bakr Muhammad Ibn Zuhr será médico de al-Manșûr. Aunque la medicina es una ciencia de los antiguos, sin embargo los Banû Zuhr no cayeron en la tentación de la otra ciencia, la filosofía, y así se salvaron de toda inquisición.

La vida de Averroes corre paralela a la del gramático Ahmad Ibn Maḍâ' (513/1119-592/1196), representante destacado del rito zâhirî. Compartieron maestros, tales como Abû Marwân Ibn Masarra, Abû l-Faḍl 'Iyậ, Abû Bakr Ibn Samahụn o Abû I-Qâsim Ibn Bashkuwâl, y discípulos. Ibn Maḍâ' abandonó Córdoba hacia el año 540/1145, cuando Ia rebelión almohade había debilitado ya a los almorávides, y emigró a la capital espiritual de los almohades, Tinmel. Allí enseñará a los hijos del califa 'Abd al-Mu'min y más tarde acompañó a uno de ellos, Abû l-Ishââ de vuelta a Córdoba. Frente a los mâlikíes, ahora se encontraba en mejor posición, pero el juez principal de Córdoba era Abû Muhammàd Ibn [al-]Mughîth, muy de temer como líder de la oposición.

Ibn Madâ' nunca fue juez en al-Andalus, pero lo fue de Bugía, quizá de Fez y finalmente qấdial-jamâ' $a$ en Marrakesh, a la muerte del anterior, en 578/1182, es decir sólo dos años después de que Averroes ocupara el cargo paralelo en Córdoba. Su muerte en Marrakesh ocurrió dos años antes de la de Averroes. ${ }^{10}$

\section{LOS ADVERSARIOS DE AVERROES}

En algunas referencias precedentes, ya han aparecido nombres de quienes se oponían a Averroes, o a su familia, como ocurría con los Banû Hạamîn. Estábamos en aquel caso frente a una familia de juristas competidora, por decirlo de algún modo, de los Banû Rushd. Algo parecido ocurre con la familia de Abû Muhammad 'Abd Allâh Ibn Mughîth conocido por Ibn aṣ-Ṣafâr, (quizá Șaffâr, «el que trabaja el cobre», el juez supremo de Córdoba que precede a Averroes. Este cordobés (nacido en 516/1122) pertenecía a una estirpe de juristas, que se remonta a la época de al-

10 Para más datos sobre su vida, véase A. Ramón Guerrero, El cordobés Ibn Madâ' (1119-1196) y la reforma de la gramática árabe, Granada, 1984, en esp. pp. 17-20. 
Hakam II. Ibn aṣ-Ṣafâr estudió con su padre Mughîth, con su abuelo Abû l-Hasan Yûnis (447/1055532/1137) - shaikh de Ibn Bashkuwâl a quien le dio una ijâza autógrafa — con un tío suyo, Abû lWalîd Ibn Yûnis, y con autoridades tales como Abû Bakr Ibn al-'Arabî o Abû Marwân Ibn Masarra. Entre sus discípulos sitúo a Abû 'Abd Allâh Ibn al-Hâjj y Abû Marwân al-Bâjîi. Durante 18 años fue juez supremo de Córdoba, probablemente hasta la fecha de su muerte, acaecida en Sevilla en Rabî‘ I 576 (julio 1180), y podemos interpretar la duración tan larga en el cargo tanto como prueba de su enraizamiento entre sus conciudadanos como de confianza por parte del sultán Abû Ya quûb Yûsuf (1163-1184). ${ }^{11}$ De su relación con Averroes no tenemos datos hasta el momento, aunque evidentemente se conocían los dos.

Averroes le sucede como juez supremo de Córdoba por esta fecha, y dos años más tarde pasa a ser médico del califa mencionado. Conocemos ya un círculo de personas relacionadas con él, que sin duda aumenta por el prestigio de su posición. Entre ellas están quienes van a dañarle, promoviendo una mihna contra los estudios de las ciencias de los antiguos, de la filosofía, pero van a pasar muchos años antes de que puedan hacerlo.

En 1194, una comisión de cordobeses se desplazó a la corte de Abû Yûsuf al-Manșûr en Marrakesh reclamando la condena de Averroes en aquellas materias en las cuales «salía de la ortodoxia.» Para cimentar su acusación, los alfaquíes se habían dedicado a leer sus obras y a recoger aquellos pasajes heterodoxos, poniéndolos en unas hojas que entregan al sultán. La audiencia no debió decepcionar a los emisarios, cuya identidad desconocemos, pues regresaron satisfechos.

Cuando el califa llega a Córdoba a comienzos de 1195, ordena a Averroes comparecer ante él y los enemigos del filósofo ven ya el castigo. Sus amigos le acompañan y esperan fuera del palacio, temiendo por la vida del filósofo. Este sale no tan sólo libre sino que además ha sido honrado por al-Manșûr, que le ha hecho sentar a su lado y ha conversado amistosamente con él. Averroes confiesa a sus amigos que el honor ha sido mucho mayor de lo que esperaba.

Dos años después de la victoria de Alarcos, es decir en 1197/8, el califa Abû Yûsuf al-Manṣ̂r se encuentra en Córdoba y cede a las presiones contra Averroes convocando una asamblea de alfaquíes en la mezquita, que se llena de gente. Esta vez sí aparecen nombres en las crónicas: Abû 'Alî al-Ḥasan Ibn Hajjjâj, Abû 'Abd Allâh Ibn 'Ayyâsh, Abû l-Husain Ibn Jubair.

Ibn Hajjjâj era de la parte de Bugía, vivió en Marrâkesh y fue varias veces a la península. En 580/1184 se convirtió en el predicador principal de la mezquita de Sevilla, pero desconozco la fecha de su cese. Como murió en Fez en 598/1202, en 1197 estaría en la península y pudo hacer muestra de sus dotes de predicador en el sermón dirigido contra Averroes. Según al-Awsî al-Marrâkushî, Ibn Ḥajjâj predicó a la gente lo que le habían mandado, y dijo que Averroes, al-Ușûlî y los demás filósofos habían renegado de su religión. Estos tuvieron que huir, a pesar de que nada escapa a la autoridad de Dios, «el que conoce el secreto y más que el secreto».

Al-Manșûr encargó a su secretario Abû 'Abd Allâh Ibn 'Ayyâsh que redactara un escrito de condena y lo enviase a Marrakesh y otros lugares. Ibn 'Ayyâsh era de Porchena, distrito de Almería; había nacido en 550/1155 y murió en Marrakesh 618/1221. Se dedicaba a la literatura, siendo maes-

11 Averroes e Ibn aș-Ṣafâr acompañaban al sultán en su fracasada expedición contra Huete, en 1172 . Ver Ibn Șạhị aṣ-Ṣalât, Al-mann bi-l-imâma, trad. A. Huici Miranda, en Textos medievales 24 (Valencia, 1969), p. 209. 
tro en el arte de la redacción. Residía en Marrakesh, en la corte almohade, donde Abû Yûsuf alManșûr le nombró șâhib al-qalam en 586/1190, cargo en el que le confirmó el califa an-Nâșir. Era pues uno de estos andalusíes al servicio del poder almohade, y que se alegraba de recibir la visita de sus compatriotas, como nos relata Abû l-Qâsim al-Balawî.

En su escrito, Ibn 'Ayyâsh aunque no menciona nominalmente a Averroes ni a los filósofos, los hace de una misma secta que existe desde antiguo, y que Dios no creó más que para el fuego del infierno. Una secta que se empeña en que el mundo es eterno y no tiene creador. Una secta que se imaginaba que el entendimiento es la razón, mîzân, del mundo y que la verdad consiste en la demostración lógica. En esencia, es un escrito que recoge las acusaciones en contra de los filósofos que Algacel formuló en su Tahâfut al-falâsifa con rigor, pero hechas de manera imprecisa, pero retórica y con las inevitables referencias coránicas.

La tercera arma utilizada contra los filósofos fue la poesía. El encargado de vilipendiar a Averroes fue Abû 1-Husain Ibn Jubair, más conocido por ser autor de un libro de viajes, una Rihla. Nació en Valencia en 539/1144, se educó en Ceuta y en Córdoba, y vivía en Granada. Su primer viaje a oriente, visitando la Meca, fue en 578 y regresó en 581; en el segundo, partió en 585 y regresó en 587. Durante su tercer viaje, que había iniciado en Ceuta y estando en Alejandría, murió el 27 Sha'bân 614 (29 noviembre 1217).

Al-Awsî al-Marrâkushî transmite 27 versos que compuso para la ocasión de la condena de Averroes. Ibn Jubair ensalza al califa y denosta a Averroes, cuyo nombre familiar significa «rectitud». Dirigiéndose al califa, dice, por ejemplo:

Dios te ha desvelado el secreto de una gente que se apartaron de la comunidad, pero que lo hicieron con hipocresía

Hicieron filosofía y se apropiaron de unas ciencias, que el que las practica sufre condena en el otro mundo.

El predicador, el secretario, el poeta que atacaron a Averroes lo hacían por encargo del califa. La cuestión es saber quien estaba detrás de las quejas y acusaciones ante el califa. Indudablemente no se trataba de una cuestión puntual, sino que como observa Abû 1-Hạjjâj Ibn 'Amr hacía tiempo que Averroes era víctima de las envidias y odios de sus rivales. Hemos comprobado ya la existencia de una rivalidad entre la familia Ibn Rushd y la Ibn Hamdîn o aquella a la que pertencía Ibn Mughîth, el anterior juez supremo de Córdoba.

El conflicto ideológico y personal aparece claramente en el caso de Ibn Zarqûn. Abû 'Abd Allâh Muhammad Ibn Zarqûn, había nacido en Jerez en 498/1 104, es decir, era bastante mayor que Averrọes. Su familia era de Sevilla, donde murió en 586/1190. Fue discípulo fiel de Abû 1-Faḍl 'Iyâd, y cuando éste era juez de Granada, Ibn Zarqûn «escribía para él». En su carrera como juez pasó por Silves, Ceuta, Niebla, el Aljarafe sevillano y Jerez. Un hijo y discípulo suyo, Abû l-Husain (539-621), que ha sido mencionado más arriba, fue también alfaquí como lo había sido su padre $\mathrm{Sa}$ î̀d, y los tres del rito mâlikí.

Maestro famoso, con gran concurrencia de estudiantes -algunos comunes con Averroes, como al-Ghâfiqî o los hermanos Ibn Hawt Allâh- escribió un compendio de al-Muntaqâ de 'Abd al-Malik al-Bâjjî̀ y luego "concilió» al-Muntaqà con el Istidhkâr de Ibn 'Abd al-Barr al-Qurțubî, produciendo una obra llamada Kitâb al-Anwâr. Experto en tradiciones - sus cadenas eran muy 
seguras - hizo también una combinación entre el Mușannaf, es decir, al-Jâmi aṣ-șahịh de Muhammad at-Tirmidhî y el Kitâb as-Sunan de Abû Dâwud as-Sijistânî.

El qâậ̉ Ibn Zarqûn afirmó que había prestado a Averroes un libro sobre las diferencias entre las escuelas de figh y que Averroes no se lo había devuelto; no nos indica el autor, solamente que era de Khorasán. Ibn Zarqûn acusa a Averroes de plagiar este libro para componer la Bidâya, añadiendo algo de los dos imames, Ibn 'Abd al-Barr, y de Ibn Hazm, al que los almohades dignificaron. Aunque se puede clasificar la Bidâya en el género de diferencias entre escuelas, es injusta la acusación de Ibn Zarqûn, quien en todo caso se ponía en evidencia: así hacía él sus libros.

Ibn Hiamdîn, Ibn Mughîth, Ibn Zarqûn: el peso de las familias de alfaquíes mâlikíes en la desgracia de Averroes es evidente, pero los almohades, ante todo Abû Yûsuf al-Manșûr, optaron por la escuela zạhirî, representada por el cordobés Ibn Ḥazm. Por otra parte, los almohades seguían a Algacel y a la reforma del Kalâm hecha por al-Ash 'arî, ¿acaso no hubo ningún zạhirí o ash'arí entre los enemigos de Averroes?

No parece que el juez que le sucedió al frente de los jueces de Córdoba fuera mâlikí. Ignoro cuándo el califa Abû Yûsuf al-Mansûr tomó esta decisión, lo más tarde en 1197; el elegido fue Abû l- 'Abbâs Yahyà al-Majrîtîi, nacido en 519/1125 y por tanto, casi de la misma edad que Averroes, con el que compartió también maestros: Abû Marwân Ibn Masarra o Abû Bakr Ibn Samajûn. Además al-Majrîtî estudió con su mismo padre, con Abû Zaid al-Khazrajî, Abû Ja'far al-Bițrûjî o Abû Bakr Ibn al-'Arabî, admirador de Algacel y su introductor en al-Andalus. Era hombre de confianza de los almohades: fue juez en Jaén, Murcia y Granada antes de ocupar el cargo más alto de la judicatura en al-Andalus, en el que se mantendría hasta su muerte en 598/1202. ${ }^{12}$

Ash'arí de nisba y de escuela fue el juez Abû 'Âmir Yahyà Ibn Rabî' al-Ash'arî, de ello no cabe duda. La enemistad con Averroes, de edad mucho mayor que él, la manifestó - nos consta por al-Anșârî al-Marrâkushî — de forma agresiva y desconsiderada. An-Nubâhî alude a su enfrentamiento con Averroes a causa de su «rechazo a aceptar nada de las ciencias de los antiguos ni a apoyarse en las opiniones de los filósofos».

Yahyà Ibn Rabî', nacido en Córdoba el 563/1168, fue discípulo de Abû l-Qâsim Ibn Bashkuwâl y de Abû 'Abd Allâh Ibn Zarqûn, del que recibió una ijâża, entre otros. Ibn Rabî‘ conocía tanto el Shâmil como el Irshâd de al-Juwainî (m. 478/1085), figura clave del ash'arismo, y él mismo compuso varias obras de Kalâm. Vivió largo tiempo en Córdoba, Sevilla, y fue juez de Málaga. Se refugió en Granada, donde el emir Nazarí Muhammad I lo nombró qậ̣̂̂ al-jamâ'a, cargo que ejerció hasta que cayó enfermo y decidió volverse a Málaga, donde murió en Rabî‘ I de 639/1241. Ibn al-Abbâr debió de confundirlo con su hermano Abû Sulaimân Rabî‘ Ibn Rabî‘ alAsh 'arî, que fue el último juez supremo - qâậ al-jamâ' $a$ - de Córdoba hasta la conquista cristiana el domingo 23 de Shawwâl de 633/1236. Rabî‘ había sucedido en el cargo a Abû l-Qâsim Ibn Bâqî, y después de la caída de la ciudad, huyó a Sevilla, donde murió poco más tarde, sin dejar obra escrita conocida.

Está claro, pues, que los enemigos de Averroes pudieron más que éste y su círculo. Desterrado a Lucena, el califa lo trajo luego a Marrakesh, donde vivía en una especie de arresto domiciliario.

12 Su sucesor fue probablemente Abû l-Qâsim Ibn Bâqî, por nombramiento de Muhammad Ibn Hûd. Ibn Bâqî es el juez anterior a Rabî‘ al-Ash'arî. 
La cuestión que ahora se plantea es saber si la prohibición califal pudo conseguir además que sus discípulos abandonaran la filosofía.

\section{DISCÍPULOS DE AVERROES}

Dos hijos de Averroes disfrutaron de las enseñanzas de su padre, Ahmad y 'Abd Allâh. El primero siguió la carrera jurídica, mientras el segundo, Abû Muhammad, fue médico y filósofo. Medicina y filosofía suelen ir unidas, y entre los discípulos médicos de Averroes debió de haber más de uno con aficiones filosóficas.

Abû Muhammad 'Abd al-Kabîr al-Ghâfiqî, el que se escandalizó porque Averroes no creía en la existencia del pueblo de 'Âd, había aprendido medicina con él. Conocemos a otros dos alumnos, Abû Ja 'far Aḥmad Ibn Sâbiq y Abû 1-Hajjâj Ibn Ṭahalûs. Ibn Sâbiq, cordobés a pesar de la nisba alMursî, fue médico del califa Muhammad an-Nâșîr, el Mirtamamolín y murió en el reinado del sucesor, Yûsuf II al-Mustanșir (1213-1224). Ibn Tahalûs, de Alcira, murió en 620/1223, y para Ibn alAbbâr fue «el último médico de Sharq al-Andalus». Ninguna fuente atestigua que se dedicaran a una ciencia prohibida, la filosofía, pero nada impide creer que la conocieran y la cultivaran.

La mayor parte de los discípulos de Averroes fueron juristas y tradicionarios. Podría enumerar otros diez, pero escogeré uno de los hermanos Ibn Hawt Allâh como muestra de aquellos que abandonaron a Averroes en su desgracia, y de los que ya conocimos uno al-Ghâfiqî.

Abû Muhammad 'Abd Allâh Ibn Hawt Allâh nació en Onda, distrito de Valencia en el año 549/1154. ${ }^{13}$ Su búsqueda del saber le llevó a Valencia, Murcia, Córdoba, Sevilla, Granda y Ceuta. En Córdoba estudió con Averroes y con el familiar de este Abû 1-Qâsim al-Warrâq, pero también con Ibn Bashkuwâl y con Abû l-'Abbâs al-Majriṭ̂i. Entresaco, de sus maestros, a Ibn Maḍ̂' en Sevilla, y a Ibn Zarqûn en Ceuta.

La carrera política de 'Abd Allâh Ibn Hawt Allâh es sorprendente: fue juez en Córdoba, Sevilla, Murcia, Ceuta, Sela, quizá Mallorca, y murió en Granada, en 612/1215, cuando se dirigía a Murcia para otra vez ser juez allí. Era un hombre de grandes conocimientos, entre ellos los uṣ̂ul, fundamentos, algo que denota que no era un mâlikí. Abû Yûsuf al-Manșûr le encargó la educación de sus hijos y si lo hizo, fue por afinidad ideológica. ¿Qué influencia pudo tener Averroes en Abû Muhammad? Diría que ninguna, pues este discípulo llegó al extremo de omitir el nombre de Averroes cuando aparecía en un hadiz.

El caso de Ibn Hawt Allâh puede ser extremo, pero no raro, y se contrapone al del visir Sahl Ibn Mâlik al-Azdî. Nació en Granada en 559/1164 y en su camino en busca del saber vivió en Málaga, Murcia, Sevilla —donde estudió con Averroes, también con Ibn Maḍâ' y con el poeta Jarâwî. Obtuvo varias ijâzas, incluso de ulemas orientales.

Cuando el imperio almohade se debilita, en buena medida por luchas sucesorias, se produce la rebelión de Abû 'Abd Allâh Muhammad Ibn Hûd, conocido por al-Mutawakkil, que se declara a favor de la causa abbasí. Cuando Ibn Hûd se adueña de Granada, Sahl es perseguido y desterrado

13 Su hermano, Abû Sulaimân Dâwûd (552/1157-621/1224) ha dejado una memoria como hombre muy piadoso. Discípulo, entre otros, de Abû l-Qâsim Ibn Rushd al-Warrâq, fue juez en Algeciras, Valencia y Málaga. 
a Murcia. Solamente después de la muerte de Ibn Hûd (Almería, 635/1238), Sahl regresa a Granada donde muere en 639/1241.

En la formación e intereses de Sahl al-Azdî destaca la lengua y la literatura. Según su discípulo ar-Ru'ainî, Sahl había estudiado desde el Libro de Sibawaihi al-Mushriq fi n-nahw de Ibn Maḍ̂, los seis poetas o las Maqâmât de Harînî, y escribió poesía y prosa. A la muerte de Averroes, compuso una risâla ta 'zîya que dirigió a lositres hijos del difunto. Sahl no tuvo miedo en honrar así, públicamente, al que fuera uno de sus maestros.

La cuestión que antes nos planteábamos, a saber, si la prohibición califal consiguió que los discípulos de Averroes abandonaran el estudio de la filosofía, puede contestarse diciendo que sin duda tuvo su efecto, pero que la filosofía fue también víctima de otro proceso: En un medio como el andalusí, en retroceso territorial, van a prevalecer aquellos estudios que refuercen la identidad cultural, es decir, los estudios religioso-jurídicos, pues, aunque los almohades abandonen el poder, los alfaquíes lo mantienen. En el resto del mundo islámico, la obra de Averroes es parcialmente conocida, pero no reconocida en su mérito:

En oriente, Averroes está en inferioridad de condiciones frente a Avicena, pero las múltiples copias que se hacen de comentarios menores en el Irán safaví atestiguan su estudio en pleno siglo XVII, estudio que se extiende también a los comentarios medios de las obras lógicas. En occidente, en Fez, Ibn Khaldiûn (m. 749/1349), conoce a Averroes por sus resúmenes - que tanto pueden ser los comentarios medios como los menores, pero no los mayores y ello gracias a su maestro Abû 'Abdallâh Muham-md al-Âbili (m. 757/1356). ${ }^{14}$ Ibn Khaldûin menciona comentarios de Averroes a las obras lógicas y a la Metafísica de Aristóteles, además de su compendio del Almagesto de Tolomeo. ${ }^{15}$ Ahora bien, en las bibliotecas de Marruecos, las copias más numerosas de obras de Averroes son las de su comentario a la Urjûza fi-t-tibb, el poema de Avicena sobre medicina, y que hacen de Averroes sólo un autor que acompañaba al estudiante de medicina en su lectura del autor principal, Avicena.

\author{
Josep Puig Montada \\ Dpto. de Arabe \\ Facultad de Filología \\ Universidad Complutense \\ 28040 MADRID
}

14 Ibn Khaldian habla de talâkhiss, en principio comentarios medios, pero no necesariamente.

Abû 'Abd Allâh Muhammad İbn Ibrâhîm Ibn 'Abd as-Salâm al-Ẩbilî, nacido en 675/1276 en Tremecén de una familia originaria de Ávila. Ver Ibn Khaldûn, Ta'rîf lbn Khaldûn wa-rịhlatuhû gharban wa sharqan, ed. M. Ibn Tâwît atTanjî (Cairo, 1951), pp. 21-22, y 33-41, donde nos da su biografía, o p. 63, para las obras de filosofía que conocía. Ibn Khaldûn se hizo su discípulo cuando al-Âbilî llegó a Túnez (p. 22), y recibió su ijâza o licencia (p. 306) . Cf. trad. francesa Abdessalam Cheddadi (París, 1980), pp. 48-51, 54-58 o 78.

Así mismo Abû 'Abd Allâh Muhammad ibn Ahmad al-'Alwî, otro de los maestros de Ibn Khaldûn, estudiaba'los talâkhîs de Averroes, además del Shifâ' y las Ishârât de Avicena (Ta'rîf, pp. 62-63).

15 Muqaddimât lbn Khaldûn wa-hiya al-juz' al-awwal min kitâb al-'ibar; Prolégomènes, ed. E.M. Quatremère, (París, 1858. Beirut, 1970), vol. 1, p. 244 (Retóica); vol. 3, p. 106 (Almagesto); vol. 3, p. 113 (9 libros del Organon); vol. 3, p. 121 (Metafisica). 


\section{BIBLIOGRAFÍA}

A continuación indico las fuentes utilizadas para este estudio. Quien desee una información detallada, con citas precisas en cada caso, puede recurrir a mi artículo «Materials on Averroes's Circle», publicado en Journal of Near Eastern Studies 51 (1992), pp. 241-260.

Ibn Khair, Abû Bakr al-Ishbîlî (1108-1179): Index de diversis scientiarum ordinibus quos a magistris dedicit Abu Bequer ben Khair. Ed. F. Codera \& J. Ribera, vol. I, B.A.H. IX, Zaragoza, 1894; vol. II, B.A.H. X, 1895.

Ibn Bashkuwâl, Abû l-Qâsim 'Abd al-Malik (m. 1182): Kitâb ạ̣-șila fî ta'rîkh a'immat al-Andalus wa'ulamâ' ihim, etc. Ed. F. Codera, B.A.H. I \& II, Madrid, 1882.

Ibn Șâhhib aṣ-Ṣalât, Abû Marwân 'Abd al-Malik (ca. 1198): Al-mann bi-l-imâma. Ed. A. al-Hâdî at-Tâzî, Beirut, 1964. Trad. esp. A. Huici Miranda, Valencia, 1969, Textos medievales 24.

AD-Dabbî, Abû Ja ‘far Ahmad (m. 1203): Bughyat al-multamis. Ed. F. Codera \& J. Ribera, B.A.H. III, Madrid, 1885.

Al-Marrâkushî, 'Abd al-Wâhịid (escrito 1224): Al-mu'jib fî talkhị̂s akhbâr al-Maghrib. Ed. R. Dozy, Leiden, 1881.

At-Tâdilî, Abû Ya 'qûb Yûsuf Ibn Yahyà (m. 1229): At-tashauwuf ilà rijâl at-tasauwuf wa-akhbâr Abî l-'Abbâs as-Sabtî. Ed. A. at-Taufîq, Rabat, 1404/1984.

Ibn 'Arabî, Muhyî ad-Dîn (1160-1240): Al-futûhât al-makkîya. Ed. 'Uthmân Yahyà, Cairo, 1392/1972 -, edición en curso.

Ibn al-Abbâr, Abû 'Abd Allâh al-Quḍ̂âî̀ (1199-1260): Takmila li-kitâb as-Silla. Ed. F. Codera, B.A.H. V \& VI, Madrid, 1889.

Ibn al-Abbâr, Abû 'Abd Allâh al-Qựầ'î: At-takmila li-kitâb aṣ-Ṣlla. Ed. I. al-'Atṭâr al-Husainî, CairoBaghdad, 1375/1955.

Ibn al-Abbâr, Abû 'Abd Allâh al-Qựầ'î: Al-mu'jam fî aṣhâab al-qâậ al-imâm Abî 'Alî aṣ-ṣadafî. Ed. F. Codera, B.A.H. IV, Madrid, 1886.

Ibn al-Abbâr, Abû 'Abd Allâh al-Quḍâ'î: Kitâb al-hulla as-siyârâ'. Ed. Ḥ. Mûnis, 2 vols. Cairo, 1963.

Ar-Ru'ainî, Abû l-Ḥasan 'Alî (1193-1266): Barnâmaj shuyûkh ar-Ru'ainî. Ed. I. Shabbûh, Damascus, 1962.

Ibn Abî Ușaibi 'a, Muwaffaq ad-Dîn (m. 1270): 'UUyûn al-anbâ' fí tabaqât al-aṭbbâ'. Ed. A. Müller, 2 vols. Cairo-Königsberg, 1299/1882. Ed. S. Az-Zain?, 4ª ed. Beirut, 1987.

Ibn Khallikân, Abû I-'Abbâs (1211-1282): Wafayât al-a'yân. Ed. I. 'Abbâs, 6 vols. Beirut, 1972.

Ibn Abî r-Rabî‘ (1202-1289): «Nașṣ barnâmaj Ion Abî 1-Rabî'». Ed. 'Abd al-'Azîz al-Ahwânî. Revista del Instituto Egipcio de Estudios Islámicos, 1, fasc. 2, (1375/1955) pp. 252-271.

Ibn Sa î̀d al-Maghribî, 'Alî Ibon Mûsà (1214-1294): Al-mughrib li-Bn Sa'îd al-Andalusî fí hulà al-Maghrib. Ed. S. Daif, 2 vols., Cairo, 1954-55.

Al-Awsî al-Anșânî al-Marrâkushî, Abû 'Abd Allâh Muhammad (m. 1303): Adh-dhail wa-t-takmila li-kitâbai al-Mawșûl wa-ș-Ṣila. Vol. I, 2 t., ed. M. Bensharîfa, Beirut, 1970. IV, ed. I. 'Abbâs, Beirut, 1965. V, 2 t., idem. VI, ed. I. 'Abbâs, Beirut, 1973. VIII, ed. M. Bensharîfa, Rabat, 1984. [Vól. VII no se conserva].

Ibn az-Zubair, Abû Ja'far Aḥmad Ibn Ibrâhîm (1230-1308): Al-qism al-akhîr min kitâb șilat aṣ-Ṣila. Ed. É. Lévi-Provençal, [Rabat, 1938] 2 ed. Beirut, 1966.

Ibn 'Idhârî al-Marrâkushî (escrito 1312-13): Histoire de l'Afrique et de l'Espagne intitulée al-Bayano'lmogrib. Ed. R. Dozy, 2 vols., Leiden, 1848-51.

Ibn Abî Zar', Abû l-Ḥasan 'Alî Ibn 'Abd Allâh al-Fâsî (escrito 1325): Al-anîs al-mutrib bi-rawḍl-qirțâs fi akhbâr mulûk al-Maghrib wa-ta'rikh madînat Fâs. Ed. M. al-Hâshimî al-Filâlî, 2 ed. Rabat, 1973. Trad.

A. Huici Miranda, Valencia, 1948. 
Adh-Dhahabî, Muhammad Ibn Aḥmad Shams ad-Dîn (1274-1348): Siyar a 'lâm an-nubalâ’, Beirut, 1981, en curso de edición.

Ibn al-Khatîib, Lisân ad-Dîn (1313-1375): A 'mâl al-a lâm. Ed. É. Lévi-Provençal, Cairo, 1956.

Ion al-Khatî́b, Lisân ad-Dîn: Al-ihâta . Ed. M.A. 'Inân, 2 vols. Cairo, 1393/1973.

An-Nubâhî, Abû l-Ḥasan 'Alî Ibn 'Ảbd Allâh (1313- ca. 1390): Ta'rîkh qudat al-Andalus sammâhu «Al-marqaba al-'ulyầ etc. Ed. É. Lévi-Provençal, Cairo, 1948. Ed. Maryam Q. Tawîl, Beirut, 1995.

Aș-Șafadî, Șalâh ad-Dîn (1296-1393): Al-wâfî bi-l-wafayât. Ed. S. Dedering, Istanbul, 1949, Bibliotheca Islamica $6 \mathrm{~b}$.

Ibn Farhûn, Ibrâhîm 'Alî (1357-1397): Ad-dîbâj al-mudhahhab fî ma'rifat a'yân 'ulamâ' al-madhhab. Ed. A.A. Shaqurûn, Cairo, 1351/1932.

Ibn al-Jazan̂, Abû l-Khair Muhammad Ibn Muhammad (1350-1429): Ghayat an-nihâya fî tabaqât al-qura' $\hat{a}^{\prime}$. Ed. G. Bergsträsser y O. Pretzl, Cairo, 1932.

At-Tunbuktî, Ahmad Bâbâ (1556-1627): Kitâb nail al-ibtihâj bi-tatrîz ad-Dîbâj. Ed. A.A. Shaqurûn, (incl. Dîbâj) Cairo, 1351/1932.

Al-Maqqarî, Abû l-'Abbâs Ahmad Ibn Muhạmmad (m. 1632): Nafh aṭtị̂b min ghuṣn al-Andalus ar-raṭ̂b. Ed. I. 'Abbâs, 8 vols. Beirut, 1968.

Ibn Sa 'îd al-Maghribî, 'Alî Ibn Mûsà: Fadâa'il al-Andalus wa-Ahlihâ li-Bn Hazm wa-Bn Sa'îd wa-sh-Shaqundî. Ed. S. Munajjid, Beirut, 1968.

Pons Boigues, Francisco: Ensayo bio-bibliográfico sobre los historiadores y geógrafos arábigo-españoles, Madrid, 1898; repr. Amsterdam, 1972; repr. Frankfurt am Main, 1993.

Encyclopaedia of Islam, $2^{2}$ edición. Leiden, 1960, en curso de publicación.

Ibn Sûda, 'Abd as-Salâm Ibn 'Abd al-Qâdir: Dalîl mu'arrikh al-Maghrib al-Aqșà. Tetuán, 1369/1950. $2^{\mathrm{a}}$ ed. Casablanca, 1960-65.

Kahhââla, 'Umar Riđ̣à: Mu'jam al-mu'allifin, 15 vols. Damasco, 1380/1960.

Al-'Abbâs Ibn Ibrâhîm: Al-i lâm bi-man hall Marrâkush wa-Aghmât min al-a' lân, 10 vols. Rabat, 1974-1983. 